yarpol@amu.edu.pl

ORCID: 0000-0001-9081-7900

Оксана Пухонська

The National University of Ostroh Academy

oksana.pukhonska@oa.edu.ua

ORCID: 0000-0003-0543-4847

\title{
Собака як спостерігач і свідок історії (за романом Вікторії Амеліної Дім для Дома)
}

Aвstract: Polishchuk Yaroslav, Pukhonska Oksana, Sobaka iak sposterihach i svidok istorii (za romanom Viktorii Amelinoi Dim dlia Doma) (The Dog as Observer and Witness of History [by the Novel of Viktoria Amelina Home for Dom]). "Poznańskie Studia Slawistyczne" 20. Poznań 2021. Publishing House of the Poznań Society for the Advancement of the Arts and Sciences, Adam Mickiewicz University, pp. 143-157. ISSN 2084-3011.

THE authors of the article analyze one of the contemporary Ukrainian novels - Home for Dom (Дім для Дома, 2015) of Viktoria Amelina. Original feature of the plot is that protagonist and narrator of this work is dog Dom (Dominic). Writer, using an animalistic hero, has achieved not only a success between readers but she also has founded a new version for emotional rethinking of the past. The matter is that Viktoria Amelina tried to reveal the peculiarities of individual, family, city and national memory. Dog's perception of the past in the novel is the author's effort to replace accents from total estimates to relative and subtle ones. Different "faces" of memory is a value which writer shows in the examples of one Lviv family history. She combines all difficult and contradictory processes of the twentieth century - wars, genocides, repression, deportation, enslavement of man and people.

KEYWORDS: family and national memory; cultural amnesia; narrator; novel; family history

В українській культурі останніх років пам'ять із категорії психологічної інтенсивно трансформується в явище суспільне, засвідчуючи активне прагнення віднайти властиве підгрунтя та утвердити власну ідентичність особи. Подібна трансформація меморіастичних практик характерна не тільки для України, вона присутня в багатьох країнах Європи та світу і є предметом активних студій сучасних дослідників (Domańska, 2012; Доманська, 2012; Lewicka, 2012; Delaperrière, 
2013; Szpociński, 2014). Ян Ассман свого часу зазначив, що культурна пам'ять - як колективне знання про минуле - $є$ запорукою усвідомлення групою власної єдності (Assman, Czaplicka, 1995, 129). Утвердження радянської ідентичності в колективній свідомості значної частини українського соціуму призвело до його ментального розколу. Особливо гострою була реакція на будь-які спроби реконструкції української пам'яті, невигідної тоталітарній ідеології колишнього режиму. Індиферентність, почасти й ворожість адептів радянської ментальності до ревіталізації національної ідентичності стала засадничим деконструкційним чинником у виникненні соціального, політичного, а нещодавно і воєнного конфліктів на території України. Відтак проблематика посттоталітарної пам'яті, що останнім часом досить потужно активізувалася в українській гуманітаристиці (праці О. Кісь, Г. Грінченко, А. Киридон, Т. Гундорової, Я. Поліщука тощо), знаходить ширший відгук у контексті згаданих вище ідентичнісних процесів (Гундорова, 2013; Киридон, 2016).

Художня література також охоче ангажується в меморіастичну проблематику, засвідчуючи тим самим її актуальність. Пам’ять минулого та право на її суб'єктивну інтерпретацію стає популярним мотивом багатьох романів останніх років: варто згадати хоча в Музей покинутих секретів Оксани Забужко (2009), Століття Якова Володимира Лиса (2010), Букову землю Марії Матіос (2019), Коханців Юстиції Юрія Андруховича (2018) та ін. Важливо, що сучасні письменники не просто відгукуються на злободенну проблему суспільного життя, а й шукають оригінальну художню форму, яка дала би змогу переконливо цю проблему відобразити. Звернення до минулого з метою переосмислення його досвіду стає одним із трендів сучасної літературної творчості.

Вікторія Амеліна у романі Дім для Дома (2015) пробує подолати стереотипну візію Львова - як ментального центру українського націоналізму, так званого „бандерштату”. Водночас саме у регіональному просторі на тлі його етнічних особливостей романістка ілюструє перехрещення різних посттоталітарних пам'ятей та пропонує шлях їхнього культурного співуживання. Прикметно, що головний персонаж роману, а водночас оповідач - це собака Домінік (Дом). Парадоксальність анімалістичного мотиву в цьому випадку полягає 
в невідповідності наратора-персонажа та об'єкта зображення. Адже Дом - тварина домашня, що звикла оцінювати людей і речі за їхньою приналежністю до певного місця. А люди, які населяють дім, стають жертвами міграційних процесів і тотального викорінення, що було основою політики радянської влади, тобто вони відчужуються від поняття домашнього вогнища. Львівська родина Ціликів, зображена в романі Амеліної, аж ніяк не є ідеальною. Її члени живуть у реальному часі й успішно пристосовуються до обставин; вони роблять успішну кар'єру в СРСР, враховують політичну кон'юнктуру та влаштовують на свій спосіб особисте життя.

Історія однієї родини (і в ширшому контексті - краю, країни), оповіджена собакою Домом, стає повчальною притчею про минуле та способи його розуміння. Образ Дома - собаки-проводиря, який супроводжує в місті незрячу дівчинку Марусю, надає творові виразної оригінальності. Відповідно до літературної традиції, тварина не тільки супроводжує людей, а й співчуває їм, прагне зрозуміти їхні інтенції (Martuszewska, 1993; Abramowska, 2010; Kuran, 2018).

На тлі ідентичнісної кризи родини Ціликів саме Дом стає тією постаттю, яка прагне повернути загублене відчуття спільної оселі, спільних цінностей. Випадає трактувати цей образ у символічному ключі, як, зрештою, також інші образи цього самобутнього роману, - цю особливість твору вже зауважили критики (Романенко, 2018). Символічні смисли виразно відлунюють у грі слів, яка має місце в назві твору Дім для Дома. Критик Ія Ківа завважує особливість анімалістичного персонажа, на відміну від персонажів-людей:

Голос пса-наратора - це голос свідка, але аж ніяк не потерпілого. Пес не рухає історію, лише коментує, тоді як люди в романі воліють мовчати і копирсатися в минулому, як у старих лахах [...]. Зрештою, в романі чи не кожен герой виявляється скринькою з подвійним дном, бо, здається, окрім пуделя, тут брешуть усі. Межа між тим, як було насправді, тим, як ми розповідаємо про те, як було насправді, і тим, яким ми це „насправді” собі уявляємо, здається надто хиткою (Ківа, 2018).

Таким чином, собака виступає в ролі свідка і своєрідного арбітра у трудній справі перечитування минулого членами львівської родини Ціликів. 
Авторка зображує місто як простір полікультурного досвіду, що виходить далеко поза власне географічні межі Львова. У цьому іiї позиція суголосна сучасним оцінкам Львова як міста 3 амбівалентною пам'яттю, яку неможливо представити в лінійній оповіді (Sosnowska, 2008; Котинська, 2015). Символічний простір міста виражає суперечливі та змішані ідентичнісні формули, як-от: позначена тоталітаризмом пам'ять репресованих та депортованих мешканців краю, піддана амнезії пам'ять Голодомору, що була привнесена у львівський контекст як елемент дискурсивної історії, а також спогади „приїжджих”. Оригінально відтворено й витіснену пам'ять австрійського, польського, єврейського Львова. Водночас письменниця критично трактує конструювання пострадянської пам'яті наприкінці XX ст.

Людські персонажі роману Амеліної виступають носіями певних групових та поколіннєвих цінностей. Це, своєю чергою, дає підстави письменниці для моделювання „арбітрального” героя: за оповідача родинної історії, а також досвіду минулого править собака Дом. Тут ідеться не лише про вербальну ревіталізацію втраченого образу минулого. Авторка представляє чуттєву рецепцію пам’яті сім’ї Ціликів, роду, регіону, народу. Через запахи квартири, вулиці, міста, околиць собака розпізнає травми минулого, в якому бачить „пульсуючі точки та цілі плями болю” (Амеліна, 2017, 610). Адже кожна стара кам'яниця Львова пропахла кров'ю і надією, причому нелегко розділити в минулому катів та жертв - настільки руйнівною виявилася тоталітарна влада. Також у назві твору міститься символ дому, що апелює до страченої пам'яті та потреби іiї віднайдення в сучасних умовах.

У романі має місце кількарівневе декодування пережитого досвіду персонажів, що стає можливим завдяки зміні епох та суспільних і морально-етичних орієнтирів. Така операція цілком логічно вписується в інтерпретаційну мапу як регіональної (західноукраїнської), так і загальнонаціональної свідомості. Можна виразно виділити принаймні три рівні сприйняття минулого. Авторка апелює до хронологічної, подієвої та поколіннєвої візії минулого.

Наративна рамка роману Дім для Дома не виходить поза хронологічні межі XX століття. Історія лише частково представлена в дискурсі пам'яті, а отже, вона не стала належно проговореним досвідом, 3 якого можна зробити належні висновки. Відтак Вікторія Амеліна 
прагне компенсувати індиферентність героїв роману щодо їхнього власного минулого, засвідчуючи важливість функціонування значеннєвої пам'яті в суспільстві, яке досі не подолало бар'єрів пострадянської трансформації.

Метафоричним персонажем роману виступає час: попри свої динамічні властивості, він набуває у творі статичного виміру. Час засвідчує непевність ситуації, в якій витіснена травма минулого не може повернутися до дискурсу сучасності. Через те календар на стіні у квартирі Ціликів, яка стає епіцентром оповіді в романі, висить із 1989 року, незважаючи на те, що час дії - 1993 рік. Варто нагадати, що 1989 рік - це період остаточного руйнування радянської цивілізації: на тлі поступового розвалу СРСР відбулося падіння Берлінського муру, перемога польської Солідарності, Румунська революція, Оксамитова революція в Чехословаччині та ін. Ефект завмирання часу в перехідні 1990-ті - художньо виправданий у романі. Адже родина Ціликів, як i інші пересічні радянські громадяни, поринає в нурт виживання під час фінансової кризи, на тлі якої особливо гострою бачиться криза культурних, духовних і моральних цінностей.

Знаковим у цьому випадку видається аспект переписування тоталітарної історії чи, радше, iї адаптації до вимог актуального часу. Ольга, донька Івана та Лілії Ціликів, - учитель історії. Опинившись у ситуації, коли радянська інтерпретація минулого, нав'язувана десятиліттями, виявилась фальшивою та неактуальною, вона переживає шок перед викликом нової доби. I якщо історія як знання у той час мала можливість самозміни через відкриття архівних документів та залучення свідчень очевидців, то спровокована конфронтацією самосвідомості пам'ять постає перед викликом самовизначення. Героїня роману переживає кризу ідентичності, чи не вперше задаючись питаннями: „хто вона?”, „звідки?”. Історія їі роду настільки заплутана і фрагментарна, що жінка почувається на роздоріжжі самоокреслення, коли звичне досі „мой адрес не дом и не улица, мой адрес..." (Амеліна, 2017, 116) більше не працює. Один із важливих викликів посттоталітарного часу полягає у відкиданні досі пріоритетної концепції інтернаціоналізму. Висловлена свого часу Джералдом Когеном теза, за якою „немає іншого способу бути людиною, окрім як належати до якогось роду” (Cohen, 1983, 229), набуває 
в цих обставинах нового смислу. Ольга розуміє, що „річ не в тім, які книжки вона тепер прочитає - картина світу в її голові не зможе отак взяти і перевернутися” (Амеліна, 2017, 117). Знання вчительки про минуле сконфронтоване пам'яттю простору, в якому заново доводиться вживатися. Вона так само легко, як і раніше російською i польською мовами, „вперше прийматиме іспити українською” (Амеліна, 2017, 105), що свідчить про багатошаровість культурного, мовного і передусім колоніального палімпсесту краю і цілої країни. Особливо незручною стає ситуація деконструкції власної системи цінностей, коли „батькові погони” і сестрин „малиновий галстук”атрибути родинної гордості - раптом набувають протилежного значення у світлі історій учнів, у яких „один дід - у Сибіру, інший у Казахстані” (Амеліна, 2017, 213) на засланні. Такого роду пам'ять у контексті власної родини авторка інтерпретує як „вирваний спогад”, котрий „не болить”.

На думку Роберта Скідельського, єдине майбутнє, яке можуть собі уявити історики - це минуле (Skidelsky, 1997, 163-164). У цьому не лише їхня „схильність до песимізму”, а й формула зміни історичної опції щодо минулого у 1990-х, коли воно виявилось абсолютно сфальшованим. А тому пам'ять - як досвід травм і прорахунків - стає фундаментальним чинником також у творенні нової парадигми історії. Для Ольги Цілик такий виклик видається непосильним, через що вона зрікається вчительської праці.

Метафорою самого часу і його таємниць у романі $\epsilon$ антикварна крамниця, з якої, за відчуттями Дома, „віє найдивнішою в світі сумішшю - ніби хтось покришив час, як салат" (Амеліна, 2017, 61). Це місце, де символічно сконцентрувались залишки втраченої у вирі XX століття полікультурної пам'яті австрійського, польського, єврейського, українського та радянського минулого Львова. Звернемо увагу на доречність запахових та смакових асоціацій у зображенні сприйняття часу анімалістичним персонажем. Історія XX століття, оповіджена через специфічні запахи, стає цікавою альтернативою для відомих історичних наративів, що ставили в основу право сильного та експлуатували мову агресії й насильства.

Дом відчуває світ безпосередньо, а минуле сприймає крізь пам'ять екзотичних запахів, які більше не повторюються - на відміну від 
людей, які переймаються морально-етичними проблемами та оцінюють дійсність у світлі моральних цінностей. Тому для собаки найбільш явним символом часу видається стара скриня у квартирі Ціликів - як таємничий артефакт минулого. Вона - чи не єдиний свідок давньої історії помешкання (тієї, що була витерта й забута), а також історії вулиці, міста, регіону. Цей символ приховує як невимовлену пам'ять, що зникла разом із колишніми мешканцями, так і необхідність іï присутності в сучасному контексті історії. Інфантильне, здавалось би, переконання дівчинки і собаки в тому, що „треба лишень знайти ключ, і одного прекрасного дня скриня відчиниться - й ось тоді львівські вулиці набудуть правильних запахів, кольорів і форм, і виведуть врешті загублених мешканців цього міста до світла, і розірвані сліди поєднаються в одну велику історію” (Амеліна, 2017, 203), водночас сприймається як знак прагнення пострадянської культури до відновлення тяглості фрагментованої тоталітаризмом пам'яті.

Минуле родини Ціликів, незважаючи на їхню дистанційовану від історії міста Лева пам'ять, видається невід'ємним від контексту сучасних трансформацій дійсності. Адже, як стверджує Ерик Клюітенберг, об'єкти та предмети, які належать до культурної спадщини певного суспільства, не можуть бути ,ізольованими тілами в деконтекстуальному гіперпросторі", їхня неминуча поєднаність засвідчує безперервність, яка виходить за рамки обмеження індивіда у часі (історичній тяглості) та просторі (властивому оточенні) (Kluitenberg, 1999, 3). А тому пам'ять минулого, незважаючи на їі неочевидну присутність у свідомості героїв роману, не може бути просто зігнорованою. Саме вона $є$ притягальною для незрячої дівчинки Марусі, сліпота якої визначає безпосередню наявність чуттєвої пам'яті помешкання, дому, родини, міста. Подібно до того, як Дом наділений гострими тваринними відчуттями довколишньої реальності, що протиставлені раціональному сприйняттю людей, Маруся втілює „паралельний світ” у емоційних судженнях та оцінках, в уявленнях про місто та світ. Вона бачить внутрішнім зором те, на що здатна людська уява у незаплямованому зовнішніми обставинами вияві. Таємниця скрині, як і таємниця роду, є для Марусі найвагомішим орієнтиром життя. Це свого роду символ цілого покоління, яке почувається незрячим у посттоталітарному світі, повному таємниць і недомовок. Скриня може виявитись 
для нього і скринею Пандори, і ключем до розгадки загадок минулого, які конче необхідні для самоідентифікації у світі під знаком усіх можливих ПОСТ-.

Художній простір пам'яті, запропонований авторкою, сконцентрований у львівській квартирі на вулиці Лепкого, яка також ховає сліди радянської квазіпам'яті, оскільки мешканці міста досі асоціюють їі з постаттю контроверсійного радянського письменника Ярослава Галана, ім'я якого вулиця носила раніше. Так, Амеліна не оминає увагою тоталітарної топонімічної практики, що формувала свідомість радянської людини. Ця практика була націлена на створення вигідної для влади інтерпретації історії, затушовування місцевого колориту та, навпаки, легітимізацію радянських маркерів місцевості. Внаслідок тривалого радянського впливу Цілики втратили автентичність: кожен iз них прагне видаватися таким, яким його хочуть бачити. I лише дівчинка Маруся та домашній пес Дом залишаються живими носіями щирої інтонації, яку в родині вже давно втрачено. У такому зображенні родинного побуту прийом персонажа-собаки, від імені якого ведеться оповідь, виглядає дуже вдалою знахідкою авторки. Наївність наратора

стишує певні акценти, але не змінює їх. Те, що за оповідача обрано пса, вирішує одразу декілька завдань: це і особлива оптика (як наслідок - можливість казати правду), і альтернативна мова опису (через запахи), і надання голосу тому, кого зазвичай позбавлено права інтерпретувати події. Бо чим, скажімо, „маленька людина", якої ніхто не помічає і не запитає іiі думки, принципово відрізняється від пса Домініка? Фраза: „Хіба не всі мають право сказати? Навіть і пуделі. Чи, ви вважаєте, не всі?” - точно відбиває актуальні нині дискусії щодо права на голос, але Амеліна ніби дає йому нове формулювання: „якщо ти є свідком подій, чи маєш ти право не сказати"? (Ківа, 2018).

Родина Ціликів, що замешкує певну квартиру із 1970-х років, також привносить свою історію в контекст регіону, міста, вулиці, будинку. На прикладі трьох поколінь Ціликів авторка ілюструє процес гібридизації ідентичності українців, що після розпаду Радянського Союзу трансформується у травму, причому ця травма по-своєму вражає кожне $з$ поколінь.

Відставний полковник, уродженець Харківщини Іван Цілик, хоча й зробив непогану військову кар'єру, проте саме тепер зазнає 
глибокої кризи ідентичності. Пережитий у дитинстві голод, незважаючи на тривале витіснення цього травматичного досвіду, продовжує переслідувати його на пенсії, вказуючи на позірність тих цінностей, які герой усе життя утверджував. Його дружина Ліля репрезентує тип особи, травмованої минулим, котре вона також під тиском обставин свідомо піддала забуттю. Адже батьки Лілі були евакуйовані в Азербайджан, дорогою до якого „згубились” усі сліди родинної пам'яті. Авторка вписує в цю історію промовисті деталі, що викривають радянську стратегію контролю і репресій, як-от вірменський погром у Баку 1990-го, наслідком чого стало введення в місто радянських військ, а згодом і спалах Карабахського конфлікту. Велика Ба - приклад індивіда без ідентичності. Ї̈̈ національність „остаточно зникла десь в потязі Москва - Львів, яким їі мати Ніна тікала востаннє від чужого погрому” (Амеліна, 2017, 78). Дім, традиції, родина, рід - те, що $є$ засадничим у формуванні власне людської ідентичності, в плині радянського трибу життя втратило і зміст, і значення. Долі старших Ціликів цілком вкладаються в парадигму зачарованих і розчарованих комунізмом (Marci, 2008).

На противагу такому викоріненню авторка Дому для Дома творить образ пані Віри - автентичної мешканки Львова, в мікросвіті, оточенні, манерах якої відображає стереотипну для регіону ментальність. На відміну від приїжджих Ціликів, пані Віра мешкає у квартирі зі своєю історією, регулярно ходить на богослужіння у Собор святого Юра. Її чоловіка назвали начебто на честь митрополита Шептицького, а сина - на честь святого Юрія. I все тут, здавалось би, цілком уписується в традиційні львівські сюжети, однак образ справжньої львів'янки далекий від ідеального. Піднімаючи лаковану завісу локальної автентики, Вікторія Амеліна показує, що навіть стійку до колонізації західноукраїнську ментальність не оминули впливи тоталітаризму. У прагненні зберегти власний простір пані Вірі свого часу довелось пожертвувати власною гідністю. Руйнівна сила XX століття стерла з пам'яті жінки чимало спогадів, у тому числі й про долю власних батьків. Орієнтиром, що не дав би загубитися у вирі того століття, був для жінки дім, де вона народилася, а тому й обман, і доноси на сусідів, і підкуп чиновників цілком виправдовувала стратегічна мета - повернути собі свій дім. Довідуючись про певні факти 
біографії пані Віри, читач поступово позбувається ілюзії щодо традиційної галицької культури, яку не раз підносили львів'яни в минулому (Gajewska, 2013; Kotyńska, 2015). Виявляється, наприклад, що iii син насправді був названий на честь радянського космонавта Юрія Гагаріна. На цьому прикладі добре видно ймовірні маніпуляції пам'яттю, до яких удаються люди в умовах несвободи чи також у постзалежному суспільстві. Пріоритетною для львів'ян стала така пам'ять, яка цілком вписувалася у культурний ландшафт регіону після розпаду СРСР.

Сестри Цілики - уже згадана вище Ольга (учителька історії) і Тамара - репрезентанти покоління, яке сформувалося на засадах цінностей радянської держави. Обидві розлучені і виховують доньок. Однак, на відміну від Ольги, яка свідома своєї квазіідентичності, Тамара легко пристосовується до умов перехідного часу. За паспортом росіянка, героїня все ж не переймається питаннями національної чи етнічної приналежності. Вона - промовистий приклад homo sovieticus, для якого національність має винятково формальний статус, а пам'ять обмежується типовими комунікативними спогадами, що не виходять поза межі сімейного дискурсу. Наявність такого типу індивіда є однією зі знакових причин відсутності стратегічної політики молодої незалежної держави щодо утвердження власної самобутності. Ідентичність нації, як і кожного ii репрезентанта, зосібна, в цьому випадку вкрай необхідний визначник. Саме ідентичність Клюітенберг визначає як „приналежність” до чогось. Ця іiї властивість, за дослідником, є незамінною для того, аби будь-яка соціальна структура була функціональною, аби виникла певна соціальна єдність (Kluitenberg, 1999, 2).

Тамара - знаковий образ, що значною мірою пояснює перехідну ситуацію 1990-х років, коли не відбувся - всупереч очікуванням патріотичної інтелігенції - ідентичнісний перелом у житті суспільства, глибоко інфікованого радянським досвідом. Натомість українське суспільство повільно реагувало на виклики часу, зокрема таким чином, що витворювало гібридні форми ідентичності. Роман Шпорлюк зауважує в цьому зв'язку, що пострадянська Україна „була не цілком новим утворенням, яке виникло на основі релігійної, етнічної чи культурної спільноти, а державою, яка претендує на роль законної спадкоємиці Української Радянської Соціалістичної республіки” (Шпорлюк, 2016, 526). Не знайшовши себе у Львові, Тамара виїздить до Іспанії, 
де, попри статус заробітчанки, бачить можливість реалізації своїх матеріальних цілей. Жінка не переймається ані минулим, ані майбутнім. Для неї життя триває туm i mепер. А тому їй відносно легко вдається пережити втечу доньки та фінансову і культурну кризу 1990-х.

Низку символічних значень продовжують долі двох дочок сестер Ціликів. Вони мають спільне ім'я Марія, проте артикульоване на різні способи. Дочка Ольги - Маруся - виразно тяжіє до духовних цінностей родини: драматично переживає розлуку з батьком, який, залишивши їх, виїхав до Америки, плекає таємні сподівання на його повернення чи переїзд до нього, захоплюється рецептами та кулінарними шедеврами бабці-львів'янки (пані Віри), сподівається врешті відкрити таємницю старої скрині, яка для неї має магічне значення. Маша, донька Тамари, живе у світі інших цінностей. Її еталон красивого життя неодмінно пов'язаний зі спогадами про Німеччину (соціалістичну НДР), де вони мешкали iз батьком-військовим, який, до речі, також покинув сім'ю. Маша постійно прагне вирватися $з$ тісного і чужого світу Львова, а тому згодом тікає у Петербург, який неодмінно асоціюється із „майже столицею” (звичайно, Москвою), звідки через кілька років повертається у Донецьк. 3 очевидних причин Схід України їй ментально ближчий. Дівчина не переймається актуальними проблемами часу. Це типовий представник покоління номадів, для яких поняття „дому” не має конкретної прив’язаності. Ї̈і пам'ять - це мікс радянського військового побуту (особливістю $є$ те, що уявлення про цей побут у дівчини пов'язані із простором за географічними межами СРСР) з численними переїздами, втратами, прагненнями і невдачами.

Зміщення травматичного часу, показане як на частковому прикладі родини Ціликів, так і на загальному - міста та країни, відбувається вже на початку 2000-х. Письменниця наголошує на умовах запізненої, але необхідної руйнації культурного і психологічного застою. Поступово все стає на свої місця, а календар у львівській квартирі на Лепкого врешті відображає актуальні дати. Проте Вікторія Амеліна не оминає увагою й новітніх травматичних подій, які почасти активізують процес посттоталітарної трансформації пам'яті. Вона вписує в родинну історію Ціликів і американський теракт 2001-го року, і Скнилівську трагедію 2002-го, і Помаранчеву революцію 2004-го. Ці різні за масштабами та причинами події зумовлюють зміни не тільки в країні 
чи світі. Вони своєрідно змінюють долі персонажів роману, зокрема сприяють возз'єднанню Ціликів навколо родинних цінностей. Це також означає, що у свідомість персонажів після тривалої кризи ідентичності повертається почуття дому як базової цінності людини.

Персонаж-собака в цій ситуації екзистенційного переходу наділений особливою ознакою - він нагадує про почуття дому як засадничу потребу людини. Нагадує про необхідність поєднання кровно споріднених, але водночас і взаємно відчужених Ціликів. Домінік доходить висновку: дім „наш, доки він в нас” (Амеліна, 2017, 381). У розбудованому наративі роману дім слід сприймати не лише як житло, місце та спільний простір мешканців. Він має й темпоральний вимір: дім Ціликів - це та пам'ять минулого, яку кожному вдалося у різний спосіб повернути й переосмислити заново в умовах іншого часу i, що найважливіше, - примиритися з нею.

Роман Вікторії Амеліної Дім для Дома видається оригінальною глосою до переосмислення історичної пам'яті в посткомуністичній Україні. Він засвідчує всю багатозначність проблеми, що виражається в конфлікті різних моделей пам'яті - як індивідуальної, так і групової. Цей твір, ніби частина мозаїки, відкриває сучасному читачеві важливі аспекти минулого, яке довший час видавалося незручним для національної культури, а нині, в нових геополітичних умовах, гостро потребує верифікації. Вікторія Амеліна не пропонує готових рецептів розв'язання конфліктів різних ідентичностей, що співіснують сьогодні в одному просторі незалежної України. Проте вона вказує на актуальну проблему, привертає увагу до іiі суперечливих аспектів.

Ефект меморіастичної ревізії, якого досягає авторка роману Дім для Дома, виглядає цілком переконливим. Передусім - завдяки художньому прийому, який покладений в основу задуму роману Вікторії Амеліної. Адже проблемний пласт твору транспоновано на образ собаки Дома: такий умовний прийом, на якому будується вся оповідь твору та який стає основою для його композиції, виявився в цьому випадку цілком виправданий. Собака Дом (Домінік) зображений у романі як своєрідний хранитель Дому, його добрий дух - на противагу тим чинникам тоталітарного минулого, які у принципі руйнують та заперечують відчуття дому, родини, затишку та спокою. Сприймаючи навколишній світ через запахи, 
Дом виражає емоції безпосередньо, на відміну від персонажів-людей, що старанно контролюють емоційне тло власного мовлення. Його умовний голос (як наратора) втілює можливість оповіді від того, хто в принципі позбавлений голосу (Ківа, 2018). У цьому сенсі анімалістичний образ цілком відповідає задумові авторки - знайти ключ до оповіді про те, що раніше соромливо замовчувалося. І спонукає читача до емоційного співпереживання згадок минулого. Водночас образ домашнього собаки слугує підкресленню ідеї спільності долі людей і тварин, яку дослідники вважають характерною рисою зображення тварин у художній літературі (Abramowska, 2010).

Характерною особливістю аналізованого роману є те, що він концентрує зображуваний досвід минулого на прикладі Львова знакового західноукраїнського міста 3 цікавою та неординарною історією. Львів має цілком солідну карту культурної пам'яті, причому в ній не бракує як етнічних, релігійних, соціальних конфліктів, так і навпаки - прикладів успішного співжиття та співпраці різних міських осередків. Вікторія Амеліна свідома цієї культурної пам'яті й активно вплітає в роман її мотиви. Водночас вона долає стереотипи, коли художньо осмислює тоталітарне минуле Львова XX століття - сторінку, яка досі мало знана й почасти замовчувана в публічній сфері. Прикметно, що завдяки анімалістичному персонажеві, яким $\epsilon$ собака Дом, авторка утверджує засади свободи й толерантності в широкому контексті, адже вони умовно поширюються не тільки на людей, що співіснують в одному просторі міста, а й на домашніх тварин, тобто характеризують атмосферу історичного міста 3 його своєрідними традиціями, попри травматичність тоталітарного досвіду, який доводиться переживати сучасникам. Конфронтація різних візій тоталітарного досвіду в контексті львівського простору вказує на те, що навіть та пам'ять, яка на сьогодні, здавалось би, значною мірою освоєна, ще криє в собі чимало білих плям на темному тлі iсторії. А тому першочерговим завданням сучасного літературного тексту є не лише шукати відповіді, а й ставити влучні запитання там, де їх помітно бракує. 


\section{Література}

Амеліна, В. (2017). Дім для Дома. Львів: ВСЛ.

Гундорова, Т. (2013). Транзитна культура. Симптоми постколоніальної травми. Київ: Грані-Т.

Доманська, Е. (2012). Історія та сучасна гуманітаристика: Дослідження з теорії знання про минуле. Пер. В. Склокіна. Київ: Ніка-Центр.

Киридон, А. (2016). Гетеротопії пам'яті. Теоретико-методологічні проблеми студій пам'яті. Київ: Ніка-Центр.

Ківа, I. (2018). Вікторія Амеліна. Дім для Дома. „Критика”, https://m.krytyka.com/ ua/reviews/dim-dlya-doma. 21.04.2018.

Романенко, О. (2018). Координати дому: символічні простори роману Вікторіі Амеліної ,Дім для Дома”. „Синопсис: текст, контекст, медіа” № 3, http://nbuv. gov.ua/UJRN/stkm_2018_3_3.31.08.2018.

Шпорлюк, Р. (2016). Формування модерних націй: Украӥна - Росія - Польщза. Пер. Г. Касьянова, М. Климчука, М. Рябчука, Я. Стріхи, Дз. Матіяш, Х. Чушак. Київ: Дух і Літера.

[Amelina, V. (2017). Dim dlia Doma. Lviv: VSL.

Hundorova, T. (2013). Tranzytna kultura. Symptomy postkolonialnoi travmy. Kyiv: Hrani-T.

Domanska, E. (2012). Istoriia ta suchasna humanitarystyka: Doslidzhennia z teorii znannia pro mynule. Per. V. Sklokina. Kyiv: Nika-Centr.

Kyrydon, A. (2016). Heterotopii pamiati. Teoretyko-metodolohichni problemy studii pamiati. Kyiv: Nika Centr.

Kiva, I. (2018). Viktoriia Amelina. Dim dlia Doma. „Krytyka”, https://m.krytyka.com/ ua/reviews/dim-dlya-doma. 21.04.2018.

Romanenko, O. (2018). Koordynaty domu: symvolichni prostory romanu Viktorii Amelinoi ,Dim dlia Doma”. „Synopsys: tekst, kontekst, media” № 3, http://nbuv.gov. ua/UJRN/stkm_2018_3_3.31.08.2018.

Shporliuk, R. (2016). Formuvannia modernykh natsii: Ukraina - Rosiia - Polshcha. Per. H. Kasianova, M. Klymchuka, M. Riabchuka, Ya. Strikhy, Dz. Matiiash, Kh. Chushak. Kyiv: Dukh i Litera].

Abramowska, J. (2010). Pisarze w zwierzyńcu. Poznań: Wydawnictwo Poznańskie.

Assman, J., Czaplicka, J.(1995). Collective Memory and Cultural Identity. „New German Critique” № 65: Cultural History/Cultural Studies, Spring-Summer, c. 125-133. https://doi.org/10.2307/488538.

Cohen, G. A. (1983). Reconsidering Historical Materialism. „NOMOS” vol. 26, c. 227-251.

Delaperrière, M. (2013). Mejsca pamięci czy pamięć miejsc? Kilka refleksji na temat uobecniania przeszłości w literaturze współczesnej. „Ruch Literacki” № 1, c. 49-61. https://doi.org/10.2478/v10273-012-0054-7.

Domańska, E. (2012). Historia egzystencjalna. Krytyczne studium narratywizmu i humanistyki zaangażowanej. Warszawa: Wydawnictwo Naukowe PWN. 
Gajewska, A. (2013). Lemberg Land, Lwiw, Lwów. Wysoki Zamek Stanisława Lema jako opowieść uchodźcy. B: P(o) zaborach, (p)o wojnie, (p)o PRL. Polski dyskurs postzależnościowy dawniej $i$ dziś. Ред. H. Gosk i E. Kraskowska. Kraków: Towarzystwo Autorów i Wydawców Prac Naukowych „Universitas”, c. 237-251.

Kluitenberg, E. (1999). The Politics of Cultural Memory, http://www.aughty.org/pdf/ politicsculturalmemory.pdf. 29.08.2008.

Kotyńska, K. (2015). Lwów. O odczytaniu miasta na nowo. Kraków: Wydawnictwo MCK.

Lewicka, M. (2012). Psychologia miejsca. Warszawa: Scholar.

Marci, S. (2008). Kawior i popioł. Życie i śmierć pokolenia oczarowanych i rozczarowanych marksizmem. Przeł. M. Szuster. Warszawa: Świat Książki.

Martuszewska, A. (red.) (1993). Literacka symbolika zwierząt. Gdańsk: Wydawnictwo Uniwersytetu Gdańskiego.

Kuran, M. (red.) (2018). Motywy fauny i flory w literaturze i kulturze. Łódź: Wydawnictwo Uniwersytetu Łódzkiego.

Skidelsky, R. (1997). The Road from Serfdom: The economic and Political Consequences of the End of Communism. New York: Penguin Books.

Sosnowska, D. (2008). Inna Galicja, Warszawa: Elipsa.

Szpociński, A. (2014). Pamięć przeszłości i strateagie legitymacyjne. B: Historia dziś. Teoretyczne problemy wiedzy o przeszłości. Red. E. Domańska, R. Stobiecki. Kraków: Towarzystwo Autorów i Wydawców Prac Naukowych „Universitas”, c. 207-216. 